\title{
Théophile Gautier: Variations on The Carnival of Venice
}

\section{On the Street}

There's an old folk tune,

Scraped by all violins,

And whined by every barrel-organ

Accompanied by barking dogs.

It's played by every musical-box,

It's a classic for all canaries.

Even my grandmother

Learned it as a child.

To this tune, cornets and clarinets

Make coquettes and bookkeepers

Dance beneath the dusty trees,

While birds flee from their nests.

The café under its bower

Of hops and honeysuckle,

Celebrates the gaiety of cheap wine and Sunday,

By blaring out the tune.

The blind man sobs it

Fumblingly on his bassoon, while near by,

His poodle, begging-bowl in mouth,

Growls along in an undertone.

Young girl guitarists,

Scrawny in their tight-fitting tartans,

Screech it out in plangent voices,

Over the tables of cafés-chantants.

But one night, unearthly Paganini,

As if with a crochet-hook, took up

The ancient air with the tip

Of his heavenly bow,

And, working upon the tattered gauze,

So the faded finery bloomed anew,

Turned the despisèd theme into

A filigree of golden arabesques. 


\section{On the Lagoons}

Tra la, tra la, la, la, la lar,

Who doesn't know the tune?

It pleased our mothers,

Tender and mocking, plaintive and gay.

The tune of 'The Carnival of Venice',

Sung on the canals in bygone days,

And borne to the ballet on sighs

of a rapturous breeze.

I seem to see, when people play it,

A gondola with a prow

Like a violin's neck, sliding

Through its blue furrow.

At a chromatic scale,

Venus of the Adriatic,

Her breast swathed in pearls,

Rises, pink and white, from the water.

The domes on the azure waves,

Follow the pure contours of the tune,

Swelling like full breasts,

That lift with sighs of love.

My skiff lands and I alight,

Casting the mooring-rope round

The pillar of a marble staircase

In front of a pink façade.

With its palaces, its gondolas,

Its seaside masquerades,

Its sweet sorrows, its mad gaieties,

All Venice lives in this melody.

A frail string vibrates and there - summoned up by a pizzicato Joyous and free, as in former days, The city of Canaletto! 


\section{Carnival}

Venice is dressing for the ball, In sequins all starry,

It sparkles, swarms and chatters away

The multi-coloured carnival.

Harlequin, negro by his mask, Serpent by his thousand hues, Gives Cassandra, his whipping-boy, A comical thrashing.

Flapping his winged sleeves,

Like a penguin on a reef,

The white Pierrot applies his powder, And blinks his eyes.

The doctor from Bologna rehearses

His endless basso patter.

Pulcinella, getting agitated,

Finds at last his crooked nose.

Colliding with Trivelin, who

Extravagantly trills in his handkerchief, Scaramouche returns to Columbine Her fan or her glove.

A mask slips at a cadence,

But it only reveals

A sly, sidelong look behind

Its eye-patches of black satin.

Ah! Fine beard of lace,

Moved by each guiltless breath,

This arpeggio said to me: 'That's her!'

In spite of her veil, I'm sure of it.

And I recognized, pink and fresh, Under the ugly cardboard mask, Her lip, beneath its peach-down, And on her chin the beauty spot. 


\section{Sentimental Moonlight}

Through the wild hilarity,

Echoing from St Mark's to the Lido,

A scale rockets upward

Like a water-jet by moonlight ...

As the tune gossips jestingly,

And shakes in the wind its little bells,

A regret, like a dove one stifles,

For a moment blends its sighs.

Far off, in the echoing mists,

As in a nearly forgotten dream,

I contemplate, still pale and sad,

My old love of yesteryear.

In tears my soul recalls

The April day when, looking

For early violets in the woods, we lay

Deep in the grass and entwined our fingers ...

That e-string note,

Vibrates like a glass harmonica,

Its thin and childish voice

A silver arrow piercing me.

A sound so unnatural, so tender,

So mocking, so sweet, so cruel,

So cold, so burning, that, on hearing it,

One feels a fatal pleasure.

And my breast, like a vault,

Weeping into its pool,

Lets fall, drop by drop,

The red tears of my heart.

Happy and sad,

Ah! Old carnival theme,

Where laughter replies to tears,

How your charms harrow me!

(Trans. M. W. Rowe) 